\title{
Factors affecting innovative technologies adoption by livestock holders in arid area of Tunisia
}

\author{
Mohamed Zied Dhraief*, Sonia BedhiaF*, Boubaker DhehibI ${ }^{\star *}$, \\ Meriem Oueslati-Zlaoul*, Oussama Jebali ${ }^{\star}$, Salah Ben-Youssef*
}

DOI: $10.30682 / \mathrm{nm} 1904 \mathrm{a}$

JEL codes: O32, Q16

\begin{abstract}
Despite the efforts to enhance adoption of innovative technologies (IT) by the Tunisian Government through national and/or international development projects, the potential rate of adoption of these technologies has remained low among farmers. This study aims at shedding some light on the potential factors that influence IT adoption in the Tunisian arid areas. Technological, economic, institutional factors and human specific factors (social) are selected to be the determinants of agricultural technology adoption. A quantitative approach employing a cross-sectional design was used to gather data. Stratified random sampling was employed and a total of 200 small-scale farmers (100 adopters and 100 non-adopters) were sampled. Data analysis and assessment was done through descriptive and statistical inferential analysis, and econometric modeling using the binary logistic regression model.

Empirical findings show that economic and socio-demographic factors such as farmer education, size of cattle flocks and off-farm income were statistically significant and had positive influence on technology adoption while age and farmer experience had significant and negative effects on IT adoption. The findings confirm the important role of institutional factors (being a member of an association, benefiting from extension services and source of technology knowledge) in the adoption decision of IT, particularly when such variables were found to be significant and positives. In contrast, labor and credit services do not significantly influence adoption of IT. Based on these results, Government should focus on educating young farmers with large cattle flock size and off-farm income to enhance the adoption of IT for livestock holders. It should also intensify training programs for farmers and for extension agents with the collaboration of the project managers and the involvement of the profession and the private sector. Finally, the open innovation strategy including all stakeholders during idea generation could be considered as a better way to decrease technology development costs and improve IT adoption.
\end{abstract}

Keywords: Adoption decisions, Innovative technologies, Livestock arid areas, Logit, Tunisia.

\section{Introduction}

In Tunisia, livestock represents $4 \%$ of the country's GDP and contributes by $41 \%$ of the total agriculture production (INS, 2016). It is mainly held by resource limited smallholders with nearly $80 \%$ of rural populations and the majority of farmers rely on traditional methods of production and this has lowered the level of productivity. Tunisian livestock sector plays a critical role in food systems facing the emerging global challenges related to climate change

\footnotetext{
* National Institute of Agricultural Research of Tunisia, El Menzah, Tunisia.

** International Center for Agricultural Research in the Dry Areas (ICARDA).

Corresponding author: dhraief.mz@gmail.com
} 
and market volatility. According to the National Observatory of Agriculture (ONAGRI, 2016), between 2007 and 2016, livestock herd size decreased annually, on average, by almost $0.38 \%$ for cattle, $1.90 \%$ for sheep and $2.94 \%$ for goat. Over the same period, the meat production has increased per year, on average, for about annually by $1.04 \%$ and $4.48 \%$ for cattle and poultry, respectively. While this production has been and decreased by $0.34 \%$ and $0.14 \%$ for sheep and goat, respectively. The increase on feed resources costs, the feed shortages during in the dry seasons, the high frequency of climatic shocks, the illegal migration of herds to the neighboring countries (Libya and Algeria), the inappropriate herd management and especially the low adoption of innovative technologies are the major factors explaining the low performance of sheep and goat sector. A study conducted by Elloumi et al. (2005) concerning the adoption and impact assessment of improved technologies in crop and livestock production systems in the WANA region (West Asia and North Africa (WANA) region reveals that); the adoption rate of feed blocks at national level was only $5.17 \%$ during 1999-2000 cropping season. Mohamed et al. (2009) confirm these findings concerning the dairy sheep breed in Tunisia called "Sicilo-Sarde" which shows low performances related to the low rate adoption rate of technical and organizational innovations.

The major challenges for policy makers to increase productivity in the livestock sector is to improve the adoption rate of innovative related livestock technologies for farmers. At the national level, the technology transfer system is essentially driven by public authorities through its various support structures, in particular the General Directorate of Agricultural Production (DGPA), the Regional Commissions for Agricultural Development (CRDA), the agricultural Training and Extension agency (AVFA) and the Office of Livestock and Pasture (OEP). The Institution of Agricultural Research and Higher Education in Tunisia (IRESA) covers the National Agricultural Research System (NARS) consisting of four complementary sets of structures and mechanisms to provide the necessary support for agricultural technologies: the re- search institutes, the institutes of higher agricultural education, the regional pole of research and development and the network of experimental stations (Khaldi et al., 2010). The current system of technology transfer presents important deficiencies related to the lack of means in the extension institutions such as the AVFA, to the lack of coordination between the various actors of the technology transfer system, particularly the profession and research, and the lack of a targeted transfer strategy that takes into account the specificity of regions and the socio-demographic and economic characteristics of farmers (Khaldi et al., 2010).

In Sidi Bouzid site, the studied area, located in Central Tunisia, a large number of small farmers are deriving most of their family income from barley/livestock-based systems. The potential of this system is explained by two facts: First, because of the double purpose that barley offer both as feed and/or food crop, and secondly because of the sheep production that is quite profitable in the region. A set of innovative technologies have been introduced in the last two decades in the livestock sector through international and/ or national development projects. The alternative feed sources have been introduced including feed blocks and treated straw with urea with the purpose to improve the nutrition of small ruminants (Nefzaoui et al., 2008, 2011a). To help communities to produce their feed blocks, an improved machine has been locally designed and manufactured to process feed blocks. Using locally available by-products, different formulas have been developed and tested by farmers; the global assessment is that the use of feed blocks resulted in increasing sheep production efficiency by $32 \%$ (Nefzaoui et al., 2008). Also, spineless cactus has been introduced in the target site and has been used as animal feed to fill the gap during drought years and dry seasons (Haddad, 2007, Nefzaoui, 2011b). In addition, new barley cultivars ("Rihane" and local accessions called Ardhaoui and Souihli) were selected by farmers and grown in demonstration fields. As well, a community-based breeding program (CBBP) has been implemented in Sidi Bouzid region to improve small ruminant productivity. In addition, improved rams were introduced 
with the purpose to reverse inbreeding and low lamb growth rates (Bedhiaf et al., 2005; 2008). Despite the introduction of these innovations by the international and national development and / or research projects, most of them are not used to create new businesses, do not reached their expected potential, and have failed in the early stage of its adoption.

Previous research studies conducted in different areas of Tunisia suggests that economic, socio-demographic, institutional and technical factors have influential roles in farmers' decisions related to the adoption of innovative and improved agricultural technologies such as the case of seeding on plant cover (Ben Salem et al., 2006), technical and organizational innovations (Aziza et al., 2009), soil and water conservation technologies (Dhehibi et al., 2018), and the conservation agriculture technologies (Fouzai et $a l ., 2018)$. However, the literature is very scarce when assessing factors influencing the adoption of livestock-related improved technologies. There is very little information available on the following technologies: Feed blocks, cactus chopper, automatic-waterer, solar milk cooling system, improved rams and improved barley varieties in Central Tunisia.

The adoption of innovative technologies by small holder famers in arid areas becomes an urgent need to improve the livestock productivity at local and national levels. Having said that, the objectives of this study are twofold: First, (i) to assess farmer's perceptions on adopting innovative technologies and secondly (ii) to determine the key factors influencing farmer's adoption decisions, and innovation diffusion processes.

This study offers and provide clear guidance and important considerations to decision-makers that could enhance adoption, sustain, and scaling of these IT in Tunisian arid agricultural areas. The present study is based on the hypothesis that adoption decision of farmers has no relationship with the type of technology.

The remaining sections of the paper are organized as follows: Section 2 deals with an exhaustive literature review on the topic. In section 3 , the methodological framework with special emphasis on the study area, data collected and source of data, and the empirical model were presented. Results and discussion of the main findings are presented in the following section (Section 4). Section 5 concludes.

\section{Literature Review}

Several empirical studies have been carried out to investigate the factors that determine agricultural technology adoption (Katungi and Akankwasa, 2010; Akudugu et al., 2012; Loevinsohn et al., 2012).The farmers' decisions about whether and how to adopt new technology are conditioned by the dynamic interaction between the characteristics of the technology itself and the array of conditions and circumstances (Loevinsohn et al., 2012). Indeed, there are number of factors that influence the extent of adoption innovation and diffusion processes of innovative technologies by smallholders' farmers such as characteristics or attributes of technology and the socio-economic and institutional context in which the technology take place (Akudugu et al. 2012).

As regards to socio-demographic factors, the farmer's education, age, experience and household size have the most influence on adoption of agricultural technologies (Fernandez-Cornejo et al., 2007; Keelan et al., 2009; Mignouna et $a l ., 2011)$. Education of the farmer has been assumed to have a positive influence on farmers' decision to adopt modern technology. In fact, education level of a farmer increases his ability to obtain; process and use information relevant to the adoption of a new technology (Lavison 2013; Namara et al., 2013). Age is considered as a determinant of adoption of modern technology. According to Mauceri et al. (2005), younger farmers are typically less risk-averse and are more willing to try new technologies than older farmers who have an increase in risk aversion and a decreased interest in long-term investment in the farm. On the contrary, Kariyasa and Dewi (2011) considered that older farmers are assumed to have gained knowledge and experience over time and are better able to evaluate technology information than younger farmers. Household size is especially used to measure labor availability. Mignouna et al. (2011) considered household size as an adoption process in that, a 
larger household have the capacity to relax the labor constraints required during introduction of modern technology.

Regarding economic factors, farm size is considered as one of the most important determinant of technology adoption. Many studies have reported a positive relation between farm size and adoption of agricultural technology (Mignouna et al., 2011, Lavison 2013). Farmers with large farm size (in terms of land or livestock herd) are likely to adopt new technologies. On the contrary, some studies have shown a negative influence of farm size on the adoption of new agricultural technology or have reported insignificant or neutral relationship with adoption (Samiee et al., 2009). Djemali et al. (2009) reported that every large farm, member of the association, was asked to back up a number of small farmers in neighboring area. Small flock holders in the region were encouraged to sell their milk through the Sicilo-Sarde breed association which doubled milk price sale after negotiating it with cheese making industry. Off farm income has been shown to have a positive impact on technology adoption. Reardon et al. (2007) considers off-farm income as an important strategy for rural households to overcome credit constraints in many developing countries. According to Diiro (2013) off-farm income is expected to provide farmers some capital for purchasing productivity enhancing inputs such as improved seed and fertilizers. Some studies on technologies that are labor intensive have shown negative relationship between off-farm income and adoption. The pursuit of off-farm income by farmers may undermine their adoption of modern technology by reducing the amount of household labor allocated to farming enterprises (Goodwin and Mishra, 2004).

Concerning institutional factors, the literature described both the positive and negative impacts of the social network on technology adoption (Katungi and Akankwasa, 2010; Conley and Udry, 2010). Katungi and Akankwasa (2010) found that farmers who participated more in community-based organizations were likely to engage in social learning about the technology hence raising their likelihood to adopt the technologies. Agriculture extension is a common method to introduce these innovative technologies. According to Mwangi and Kariuki, (2015), availability and access to extension services has also been found to be a key aspect in technology adoption. Many authors have reported a positive relationship between extension services and technology adoption (Mignouna et al., 2011; Mwangi and Kariuki, 2015). Akudugo (2012) has explained that access to extension services can counteract the negative effect of lack of formal education of farmers, which hinders technology adoption. In developing countries, extension agents usually select a particular contact farmer who is recognized as the most influential agent to deliver new technology (Silva and Broekel, 2016). Access to credit is considered as one of the most important determinant of technology adoption. According to Simtowe and Zeller (2008), access to credit promoted the adoption of risky technologies through relaxation of the liquidity constraint as well as through the boosting of household's-risk bearing ability. Acquisition of information about a new technology is another factor that determines adoption of technology. Khalid et al. (2017) indicated that the information obtained directly from the project manager has a positive influence on technology adoption. This is an indication of the importance of obtaining accurate and sufficient information on the nature of the technology and what benefits can be achieved when using it, which is an incentive to encourage farmers to adopt technology.

\section{Methodological Framework}

\subsection{Study Area}

The data was carried out in the governorate of Sidi-Bouzid located in Central Tunisia (Fig. 1) which is characterized by low levels of economic activity, high incidence of droughts and a high concentration of rural population $(75 \%)$. It covers an area of $7405 \mathrm{~km} 2$ and it is characterized by an arid climate with an annual rainfall between 200 and $300 \mathrm{~mm}$. It was for many years ago disfavored in terms of infrastructural and institutional support. Beside the limited natural resources, particularly arable land and water, a 
large number of the small farmers are deriving most of their family income from barley/livestock based systems and sheep fattening practice is quite profitable in the region. In fact, the Sidi-Bouzid region produced in 2014 a total of 325,000 lambs and for the Aid el Edha festivity, this governorate contributed by $38 \%$ of the total national lamb production (Bedhiaf et al., 2016).
According to national statistics, Sidi-Bouzid governorate is ranked number one nationwide in terms of collected cattle milk with a contribution of $293,000 \mathrm{l} /$ day ( 11 to $15 \%$ of the national volume). The dairy cattle population is about 35,000 cows owned in the majority by small producers ( $\leq 6$ cows) with a daily production volume of 20 to 60 liters per farm (INS, 2016).

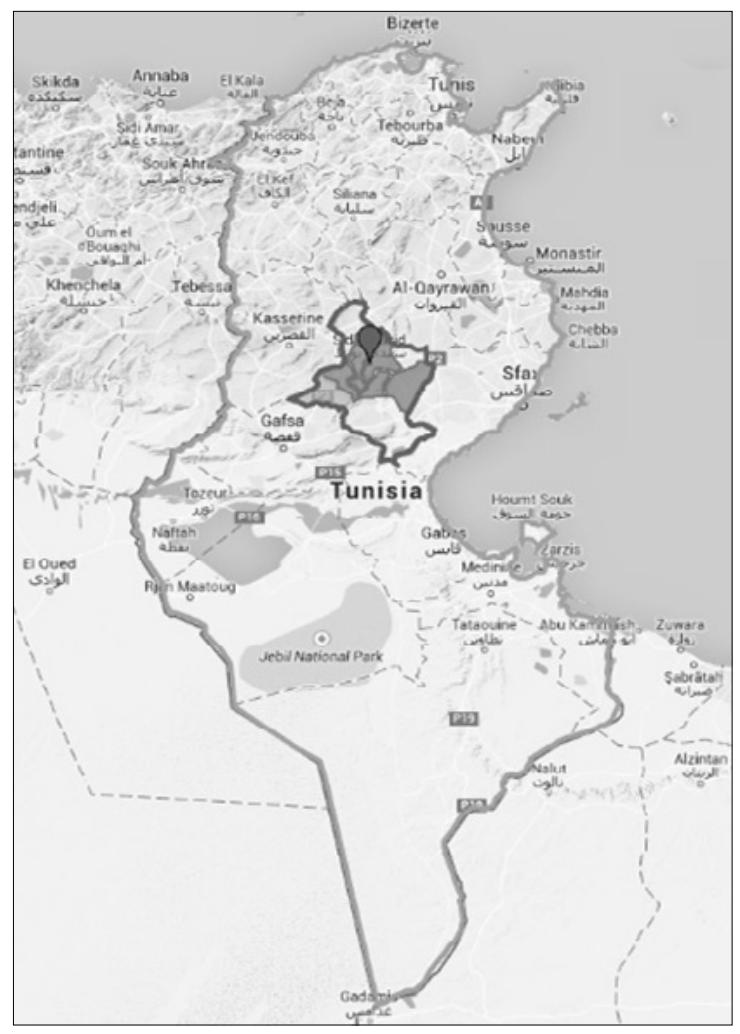

Figure 1 - Map of the study site in Tunisia.

\subsection{Innovative livestock technologies}

In this study, six innovative technologies have been selected: feed blocks, cactus chopper, automatic-waterer, solar milk cooling system, improved rams and improved barley varieties. These technologies have been introduced by different international development projects as the project "Provision of proven feed resource technologies to improve the red meat value chain in Tunisia" in 2015, the project "Field testing of an innovative solar powered milk cooling solution for the higher efficiency of the dairy subsector in Tunisia" in 2015, the CGIAR Research Program (CRP) on "Integrated Agricultural Production Systems for Improved Food Security and Livelihoods in Dry Areas" in 2013, the Mashreq/ Maghreb project "The development of integrated crop/livestock production in low rainfall areas of Mashreq and Maghreb regions" in 1995. There are also national development projects which were established during the last decade 
with the collaboration of the Livestock and Pasture office, the main actor promoting innovative technologies to farmers.

\subsection{Data Collection and source of data}

The data were drawn from a sample size of 200 farmers in Sidi-Bouzid area, using a stratified random sampling technique; 100 adopters and 100 non-adopters (neighbors) of innovative technologies. The distribution of the sample collected and sample size from the different locations and technologies are displayed in the table below (Table 1).

Before launching the survey, the questionnaire was tested in the target areas. Pre-testing the questionnaire provided an opportunity to make some modifications and to improve the field survey. The questionnaire was used to collect the data through face-to-face interviews. The data collected was reviewed and verified. Then, data was coded and edited. Microsoft Excel and Statistical Package for Social Sciences (SPSS) were used for analysis. The information collected using the questionnaires covering several sections included information about farmer's socio economic conditions, natural capital, flock size, access to credit, engagement in community based organizations, farmers' knowledge of the innovative technologies, perception for technology adoption and attitudes for the technology transfer strategies.

Table 1 - Distribution of sample by location.

\begin{tabular}{|l|l|l|l|}
\hline Farmers groups & Innovative Technologies & Location & No. offarmers \\
\hline & Feed blocks & Hania & 15 \\
& Cactus chopper & Zoghmar & 18 \\
& Automatic Waterer & Zitouna, & 17 \\
Adopters & Solar milk cooling system & Hania, Zitouna & 7 \\
& Improved rams & Zitouna, Regueb, Zitouna & 23 \\
& Improved barley varieties & Sidi Bouzid area & 20 \\
& Total & SidiBouzid area (neighbors) & 100 \\
\hline Non-adopters & Without technologies & & 100 \\
\hline
\end{tabular}

\subsection{Conceptual Framework: logit model}

Modeling a relationship between the decision to adopt and not to adopt an innovative technology with the observed factors requires the use of qualitative response models. Commonly used models of this type are probit (which assumes an underlying normal distribution) and logit models (which corresponds to a logarithmic distribution function). Both the logit and probit models yield similar parameter estimates and it is difficult to distinguish them statistically (Aldrich and Nelson, 1984). The logit model was used in this study since it is easier and simpler to interpret and thus has been widely applied in adoption studies (Ng'ombe et al., 2014; Akrouch et al., 2017).
The adoption decision by farmers is specified as:

$$
\mathrm{Z}_{\mathrm{i}}=\beta_{0} \sum_{\mathrm{i}=1}^{\mathrm{n}} \beta_{\mathrm{i}}+\beta_{\mathrm{i}} \mathrm{X}_{\mathrm{i}}, \ldots \ldots \ldots .
$$

Where is a constant and $Z_{i}$ is equal to one (1) when a choice is made to adopt and zero (0) otherwise; this means: The equation represents a binary choice model involving the estimation of the probability of adoption of a given technology (Z) as a function of independent variables (X). Mathematically, this is represented as:

$$
\begin{gathered}
\operatorname{Prob}(Z=1)=F\left(\beta^{\prime} X_{i}\right) \\
\operatorname{Prob}(Z=0)=F\left(1-\beta^{\prime} X_{i}\right)
\end{gathered}
$$


Where $Z_{i}$ is the observed response for the $i^{\text {th }}$ observation of the response variable, $Z$. This means that $Z_{i}=1$ for an adopter (i.e. farmers who adopt modern agricultural production technologies) and $Z_{i}=0$ for a non-adopter (i.e. farmers who do not adopt modern agricultural production technologies). $\mathrm{Xi}$ is a set of independent variables such as farm size, family size, education of household head, among others, associated with the $i^{\text {th }}$ individual, which determine the probability of adoption, (P). The function, may take the form of a normal, logistic or probability function. The logit model uses a logistic cumulative distributive function to estimate, $\mathrm{P}$ given z by,

$$
\begin{gathered}
\operatorname{Pr}(\mathrm{Y}=1 / \mathrm{X})=\frac{\mathrm{e}^{\mathrm{z}}}{1+\mathrm{e}^{\mathrm{z}}}(4) \\
\operatorname{Pr}(\mathrm{Y}=0 / \mathrm{X})=1-\frac{\mathrm{e}^{\mathrm{z}}}{1+\mathrm{e}^{\mathrm{z}}}(5) \\
\mathrm{Z}=\beta_{1} \mathrm{X}_{1}+\beta_{2} \mathrm{X}_{2}+\cdots+\beta_{\mathrm{K}} \mathrm{X}_{\mathrm{K}}=\sum_{\mathrm{i}}^{\mathrm{k}} \beta_{\mathrm{i}} \mathrm{X}_{\mathrm{i}}
\end{gathered}
$$

Where $\mathrm{k}$ represented number of independent variables to be analyzed in the study. Since the model is non-linear, the parameters are not necessarily the marginal effects of the various independent variables. The maximum likelihood method was used to estimate the parameters. The empirical model for the logit model estimation is specified as follows:

$$
\mathrm{Z}_{\mathrm{i}}=\ln \left(\frac{\mathrm{P}}{1-\mathrm{P}}\right)=\alpha+\beta_{\mathrm{i}} \mathrm{X}_{\mathrm{i}}+\delta_{\mathrm{i}}
$$

Where the above formula is called log of odds ratio and $\mathrm{Xi}$ is the combined effects of $\mathrm{X}$ explanatory variables that promote or prevent farmers ${ }^{\text {ce }}$ decision to adopt modern agricultural production technologies". In other words the model $\ln \left(\frac{\mathrm{P}}{1-\mathrm{P}}\right)$ in the formula represents log-odds in favor of farm householdse ${ }^{\text {ee }}$ decision to adopt modern agricultural production technologies or not to adopt. It is the logarithm of the ratio of probability of adopting the technologies (p) to probability of not adopting them (1-p). The ratio $\left(\frac{\mathrm{P}}{1-\mathrm{P}}\right)$ shows the odds ratio of probability of adopting the technology to not adopting it. That means it is the ratio of probability of adopting the technology (p) to not adopting the technologies (1-p) in the observational studies.

\subsubsection{Description of variables and hypothe- ses used in Binary Logistic Regression}

Farmers' use of technologies can be influenced by various socio-economic factors, socio-demographic, and institutional factors (Table 2). Thus, the survey was conducted to understand farmer's view of technology and factors affecting in apply and adoption of technology. The model included seven explanatory variables and represented the factors supposed to influence the adoption and diffusion processes of innovative technology in the study area.

Studies have indicated that an individual's adoption of innovation not only depends on individual attitudes but also on economic, organizational policies, approaches and actions. It is within this framework and on the basis of indepth descriptive statistics, the variables with a strong influence on the individual's adoption and diffusion processes of IT in the target area have been selected.

These variables were:

AGE: It is a quantitative variable. Age was hypothesized to have a negative relationship with the propensity to adopt precision agriculture technologies. The general notion found from the introduction of new technologies both within agriculture and outside of it is that older generations are the last to adopt them, while the younger generations typically embrace them more quickly.

EDU: It is a qualitative variable. Education may promote adoption of new technologies by increasing household's access to information and ability to adapt to new opportunities. It is expected that EDU have a positive impact on adoption.

FEXP: It is a quantitative variable. This variable measures the average of the livestock owner's experiences' in dairy sector and would be expected to show a negative sign. This is indicating, as a result of the fact that most of the farmers adopting an innovative technology are young livestock owners that those with long experience are more adhering to traditional methods of farming, and are less receptive to adopting modern technologies. 
LABE: It is a quantitative variable. This variable measures the size of the active-labor force. The presence of a larger active-labor have a positive influence on the adoption of modern technologies.

CRED: It is a qualitative variable. This variable measures the accessibility of livestock owners to cash credit and consequently to innovative technologies. The CRED dummy variable would be expected to exert a positive influence on adoption of modern technologies.

MEMA: It is a qualitative variable. Being a member of an association can help livestock owners to have information on modern technologies and to have also more opportunities to adopt them.

COWN: It is a quantitative variable. This variable measures the number of cattle heads. Livestock owners with a high flock size have a higher propensity to adopt innovative technologies than the small livestock owners.

INCSO: It is a qualitative variable. This variable measure if the breeder has non-agricultural activity (off-farm income) or only agricultural activity (farm income). The INCSO dummy variable may influence negatively or positively the adoption of modern technologies.

EXTSER: It is a qualitative variable. This variable measures the accessibility of livestock owners to extension services. The CRED dummy variable would be expected to exert a positive influence on adoption of modern technologies.

SINF: It is a qualitative variable that refers to the source of information about the technique (1: project manager, 0 : others). The communication of information from the project manager to the livestock owners directly has an effect on the increased probability of adopting the technology.

Table 2 - Variables used in the empirical binary Logistic model.

\begin{tabular}{|c|c|c|c|}
\hline Acronym & Description & Type of measure & Expected sign \\
\hline \multicolumn{4}{|c|}{ Dependent variable } \\
\hline ADOP & Whether a farmer has adopted or not & Dummy ( 1 if yes, 0 if no) & \\
\hline \multicolumn{4}{|c|}{ Explanatory variables } \\
\hline AGE & Household head's age & Years & - \\
\hline EDUC & $\begin{array}{l}\text { Educational background of the } \\
\text { household head }\end{array}$ & Dummy ( 1 if yes, 0 if no) & + \\
\hline FEXP & Household head's farming experience & Years & - \\
\hline INCSO & Income sources & $\begin{array}{l}\text { Dummy ( } 1 \text { if farm income, } \\
0 \text { if non-farm income) }\end{array}$ & $-/+$ \\
\hline EXTSER & Extension services & Dummy ( 1 if yes, 0 if no) & + \\
\hline LABE & Labor force size & Active labor force Numbers & + \\
\hline CRED & Obtained credit & Dummy ( 1 if yes, 0 if no) & + \\
\hline MEMA & Member of association & Dummy ( 1 if yes, 0 if no) & + \\
\hline COWN & Cattle ownership & Number of heads & + \\
\hline SINF & Source of technology knowledge & 1 , project manager, 0 : Others & + \\
\hline
\end{tabular}

\section{Results and discussions}

\subsection{Criteria for innovative technologies adoption decision}

The degree of adoption of any innovative technology depends largely on its characteris- tics. Rogers (1961) identified five characteristics that affect the rate at which an innovation is adopted: relative advantage, compatibility, complexity, divisibility (triability), and communicability (observability). According to Rogers (1995), farmers may learn from their 
own experimentation, from agricultural extension services in the area, and from neighboring farmers. In the case of developing countries, farmers often learn through the social learning approach. Rogers (2003) has drawn attention to an adoption category based on the innovation decision period. The innovation-decision period is the length of time required to pass through the innovation-decision process. In this study, numerous technologies attributes were selected to understand their importance on the adoption decision of IT (Table 3).

A Likert scale of five, strongly agree (5) and strongly disagree (1) was used to assess the above-mentioned characteristics of adopters of innovative technologies at the targeted zone. The result indicates that the farmers evaluate differentially the adopted innovative technologies (Table 3 ). The farmers agreed to adopt feed blocks because it reduces risk, the technology is triable, reversible, easy to follow up and compatible with production system. However, this technology needs know-how. For cactus chopper, the farmers adopt this technology because it reduces production costs and risk, the technology is especially affordable, compatible and easy to implement and to follow up. The solar milk cooling system technology is adopted because it has environmental benefits and the support of agricultural policies (subsidizes), this technology is triable but complex, not affordable and needs know-how. The farmers agreed to adopt improved ram's technology because it increases profit, is communicable, easy to implement and follow up and has the support of agricultural policies. The improved barley variety is adopted by farmers because it reduces risk (high temperature), increase profits and is easy to implement and to follow up and has the support of agricultural policies. The farmers agreed to adopt automatic waterer because it reduces risks and is easy to follow up, compatible, communicable and triable. However, this technology needs know-how.

Table 3 - Criteria for innovative technologies adoption decision.

\begin{tabular}{|l|l|l|l|l|l|l|}
\hline & Feed blocks & $\begin{array}{l}\text { Cactus } \\
\text { chopper }\end{array}$ & $\begin{array}{l}\text { Solar milk } \\
\text { cooling } \\
\text { system }\end{array}$ & $\begin{array}{l}\text { Improved } \\
\text { rams }\end{array}$ & $\begin{array}{l}\text { Improved } \\
\text { barley } \\
\text { varieties }\end{array}$ & $\begin{array}{l}\text { Automatic } \\
\text { waterer }\end{array}$ \\
\hline Easy to implement & 3.1 & 4.5 & 3.1 & 4.4 & 4.5 & 4.2 \\
\hline Easy to follow up & 4.1 & 4.5 & 3.7 & 4.5 & 4.5 & 4.7 \\
\hline Compatible & 4.1 & 4.7 & 3.2 & 4.5 & 4.6 & 4.7 \\
\hline $\begin{array}{l}\text { Agricultural policies } \\
\text { support }\end{array}$ & 3.2 & 3.1 & 4.7 & 4.5 & 4.7 & 3.1 \\
\hline Complex technology & 3.7 & 1.2 & 4.7 & 1.9 & 1.8 & 3.2 \\
\hline $\begin{array}{l}\text { Environmental } \\
\text { benefits }\end{array}$ & 3.1 & 2.8 & 4.8 & 3 & 3.2 & 3.2 \\
\hline Reduce risk & 4.6 & 4.8 & 1.1 & 1.1 & 4.8 & 4.9 \\
\hline Needs know-how & 4.6 & 2.7 & 4.6 & 1.7 & 3.2 & 4.2 \\
\hline Affordable & 3 & 4.9 & 1.1 & 3.6 & 4.1 & 3.1 \\
\hline Communicability & 3.9 & 4.5 & 4.1 & 4.5 & 4.2 & 4.2 \\
\hline Triable & 4.4 & 4.8 & 4.7 & 3.9 & 4.5 & 4.2 \\
\hline $\begin{array}{l}\text { Reduces production } \\
\text { costs }\end{array}$ & 3.8 & 4.8 & 3.2 & 3 & 1 & 2.1 \\
\hline Increase profits & 3.9 & 4.2 & 2.7 & 4.5 & 4.1 & 3.7 \\
\hline Divisibility & 2.9 & 4.2 & 1 & 1 & 1 & 1.9 \\
\hline Mean & 3.7 & 3.8 & 3.3 & 3.3 & 3.6 & 3.7 \\
\hline
\end{tabular}




\subsection{Descriptive Statistics}

The descriptive statistics for the variables used in this study are presented in Table 4. There are three major columns showing a description of the total sample, adopters of innovative technologies (IT) and non-adopters. Within these columns are the variable means and their standard deviations for the total sample, IT adopters and non-adopters. The average age of the household head for the total sample was 47 years while for IT adopters, it was 44 years. For the non-adopters, the household head's average age was about 51 years. The level of education of the household head was categorized into two levels; educated and uneducated. An average of $88 \%$ of farm households that adopted IT had acquired at least primary education. The level of education for total sample was high (71\%). For the non-adopters, the household head's education level was about 53\%. The average farm experience of the household head for the total sample was 20 years while for IT adopters, it was 23 years. For the non-adopters, the household head's average farm experience was about 53 years. The average labor force size for the total sample and for both groups was about 4 members. Results show that about $44 \%$ of the households in the total sample had off-farm income while $58 \%$ of IT adopters and about $29 \%$ of the non-adopters had only farm income. In terms of cows owned, the average of the flock size was about 13 heads while for IT adopters, it was 18 heads. For the non-adopters, the average was 8 heads. Concerning institutional factors, the majority of IT adopters had access to extension services (91\%). However, almost a third of the IT adopters area member of an association and had access to loans. In addition, results show that $76 \%$ of IT adopters had access to information about technologies from project manager.

Table 4 - Descriptive statistics of variables used.

\begin{tabular}{|c|c|c|c|c|c|c|}
\hline & \multicolumn{2}{|c|}{ Total sample } & \multicolumn{2}{|c|}{ Adopters } & \multicolumn{2}{|c|}{ Non-adopters } \\
\hline Variable & Mean & Std. Dev. & Mean & Std. Dev. & Mean & Std. Dev \\
\hline AGE & 47,60 & 11,799 & 43,81 & 9,901 & 51,39 & 12,361 \\
\hline EDU & 0,71 & 0,457 & 0,88 & 0,327 & 0,53 & 0,502 \\
\hline FEXP & 20,18 & 10,429 & 17,60 & 8,633 & 22,76 & 11,431 \\
\hline LABE & 3,87 & 2,138 & 3,90 & 2,190 & 3,83 & 2,094 \\
\hline INCS & 0,44 & 0,497 & 0,58 & 0,496 & 0,29 & 0,456 \\
\hline COWN & 13,18 & 18,273 & 18,32 & 23,873 & 8,04 & 6,924 \\
\hline EXTSER & 0,71 & 0,455 & 0,91 & 0,288 & 0,51 & 0,502 \\
\hline MEMA & 0,30 & 0,457 & 0,36 & 0,482 & 0,23 & 0,423 \\
\hline CRED & 0,28 & 0,450 & 0,34 & 0,476 & 0,22 & 0,416 \\
\hline SINF & 0,58 & 0,496 & 0,76 & 0,429 & 0,39 & 0,490 \\
\hline
\end{tabular}

\subsection{Binary regression model results}

The coefficients of the binary logistic regression model were estimated using the Maximum Likelihood Method (ML) by SPSS Program. The quality of conciliation was tested using the Hosmer and Lemeshow statistic, which is one of the most reliable test to reconcile the logistic regression model. The results of the model are given in Table 5. The overall percentage of correct predictions is about $78.5 \%$. The p-value 0.579 uses the Hosmer and Lemeshow Goodness-ofFit Test, which is computed from the Chi-square distribution with 8 degrees of freedom (d.f), 
which confirms that the model's estimates fit very well the data. This implies that we accept the null hypothesis that there is no difference between the observed values and the estimated values of the dependent variable (Sidibe, 2005).

The column exp (B) in Table 5 gives the exponential of expected value of $\beta$ raised to the value of the logistic regression coefficient, which is the predicted change in odds for a unit increase in the corresponding explanatory variable. The Table 5 showed that 8 explanatory variables were found to be significant at the level of $1 \%$ and $10 \%$. These were EDU, EXTSER, COWN and SINF variables which showed their significance at $1 \%$ and FEXP and MEMA at 5\% and Ageand INCS at $10 \%$. The rest of the variables (LABE and CRED) were consistent in terms of reference but did not prove their significance at the level of the model. The logistic regression equationis expressed as following:

$\mathrm{ADOP}=-2,421-0,033$ AGE +1,775 EDU $-0,053$ FEXP -0,012 LABE +0,725 INCS +0,118 COWN +1,665 EXTSER +1,016 MEMA -0,132 CRED +1,495 SINF

Results showed that age is statistically significant for the adoption or not of IT. The negative sign of the coefficient of age of the household head implies that the age of the household head decreases the odds of adopting IT. This result is in conformity with literature review where younger farmers have a higher propensity to adopt technologies than the older farmers. The variable EDU is statistically significant and positively affect the adoption of IT. This implies that adoption increases when the farmer have at least a primary level of education. This result confirms the literature review of the positive influence of the education of the farmer on adoption technologies. The variable labor force size (LABE) is statistically non-significant and have no impact on the decision to adopt IT. This seems to be explained by the fact that farmers do not need much labor force especially for the mechanized technologies. As hypothesized, the farmer experience (FEXP) coefficient was also found to be significant and negatively correlated with the adoption decision at the $5 \%$ level of significance. The result confirms the fact that most of the livestock owners adopting an innovative technology are young, those with long experience are more adhering to traditional methods of farming, and are less receptive to adopting modern technologies. The income sources INCS (availability of off-farm income) is statistically significant at affecting adoption of IT in Tunisia. Results indicate that off-farm incomes increase the odds of adopting IT among farmer. This seems to be explained by the fact that farmers' major sources of income are off-farm activities and that they would more likely invest in agricultural technologies. In general, farmers with high income do not need to have access to loans and are more likely to adopt IT. The cattle's ownership COWN is statistically significant at affecting adoption of IT in Tunisia. The adopting increase in variable COWN by one unit will increase the probability of IT adopting by 1.125 times. Results indicate that larger farmers that have large flock size of cattle would more likely adopt CT in Tunisia especially for the technology with high cost (Solar powered milk cooling technology, feed block manufacturing machine).The extension services variable EXTSER was also found to be significant and positively correlated with the adoption decision at the $10 \%$ level of significance. This implies that adoption increases when farmer have access to extension services. This result indicates the major roles of extension services on dissemination of innovative technologies in Tunisia. The association member variable MEMA was statistically significant at affecting adoption of IT in Tunisia. This indicated that the adoption of IT increased when the farmer is a member of an association. In this direction, this form of organization can help their members to have information about modern technologies, to give some advantages in terms of access to credit and to sustain the development of the sector by a trilogy principle where farmers, researchers and policy makers interacted together to find the optimum solution that fits the expressed needs of its members. The results showed that institutional variables such access to credit (CRED) have no impact on the decision to adopt IT. This indicates that there are many constraints for farmers to have access to credit in Tunisia (lack of land title, high interest rate, etc.). The source of technology knowledge variable SINF is statistically 
significant at affecting adoption of IT in Tunisia. This indicates that the adoption of IT increased when the information on technology is obtained directly from the project manager. This result confirmed the hypothesis that the project man- ager has the most comprehensive information on technology and he is the most convincing for its adoption. Project manager needed to be more involved in the training of farmers for enhancing the adoption decision.

Table 5 - Parameter estimates of the binary logistic regression model for factors influencing adoption of innovative technologies.

\begin{tabular}{|l|l|l|l|l|l|}
\hline Variable & $B$ & S.E. & Wald & Sig. & $\operatorname{Exp}(\beta)$ \\
\hline AGE* & $-0,033$ & 0,020 & 2,796 & 0,095 & 0,968 \\
\hline EDU*** & 1,775 & 0,504 & 12,404 & 0,000 & 5,899 \\
\hline FEXP** & $-0,053$ & 0,022 & 5,678 & 0,017 & 0,948 \\
\hline LABE & $-0,012$ & 0,094 & 0,017 & 0,896 & 0,988 \\
\hline INCS* & 0,725 & 0,415 & 3,047 & 0,081 & 2,065 \\
\hline COWN*** & 0,118 & 0,035 & 11,089 & 0,001 & 1,125 \\
\hline EXTSER*** & 1,665 & 0,507 & 10,790 & 0,001 & 5,283 \\
\hline MEMA** & 1,016 & 0,443 & 5,254 & 0,022 & 2,763 \\
\hline CRED & $-0,132$ & 0,439 & 0,091 & 0,763 & 0,876 \\
\hline SINF*** & 1,495 & 0,459 & 10,610 & 0,001 & 4,462 \\
\hline Constante** & $-2,421$ & 1,231 & 3,869 & 0,049 & 0,089 \\
\hline
\end{tabular}

Hosmer and Lemeshow Test: Chi-square, 6.608; df., 8; Sig., 0.579; -2 Log likelihood, 159,842a; Cox \& Snell R Square, 0.444; Nagelkerke R Square, 0.592; The overall percentage of correct predictions, $78.5 \%$; *Significance at $10 \%$.* Significance at $5 \%$; *** Significance at 1\%; Source: Own elaboration from model results (2018).

\section{Conclusions and Recommendations}

For a long time, the question of technology dissemination has been posed keenly by decision makers in agriculture and especially in the livestock sector where productivity remains low. In addition, numerous development projects promoting innovative technologies have been launched in the arid zone characterized by difficult climatic conditions. However, the majority of farmers stop using the innovative technology once the project achieved. This study was conducted to enhance our understanding of factors influencing the adoption of innovative technologies in an effort to provide insights on pathways to increase their adoption in Tunisia.

The Results of binary logistic regression showed the importance of economic, socio-demographic and institutional characteristics of farmers in the adoption of IT. The main factor contributing to adoption of innovative technologies is education. According to the national sta- tistic in 2014, the illiterate rate in this area was about $29.2 \%$ for the population of Sidi-Bouzid governorate. This rate is higher in the rural area. This result enhances the decision makers to pay more attention to the education level of farmers, to guide the techniques towards more educated farmers, which positively reflects on the possibility of increasing the adoption innovative technologies. In another way, it is essential to reinforce the adult literacy program for farmers, initiated by the government in 2000 especially in the arid area of Tunisia. It is also necessary to fight the number of young people who drop out of the school system early in the rural area. The negative sign of the coefficient of the variable AGE of the farmers implies that there is a time in life of the household head, when age would no longer positively affect the adoption of agricultural technologies, the relationship that relates to the life cycle hypothesis in economic theory (Ng'ombe et al., 2014). The lessons learned that could be shared from this study are 
exiting. Some of the most important lessons we learn come from the need to focus on targeting the young farmers group when promoting an innovative technology. In this regard, one of the success conditions for technology adoption is to collaborate and partnership with young farmers in the initial phase of the process and in the second stage with the older ones. Otherwise, the farmers face many challenges such as weather conditions, high prices of agricultural inputs, low productivity and low selling price which implies in abandonment of agriculture to young people. The government should give a lot of encouragement to young farmers to remain in the agricultural activity and then boost the technology dissemination.

The study showed the importance of the offfarm income in the adoption of IT. The low farm income is an important constraint for farmer to access to technology. In addition, the majority of farmers in Sidi-Bouzid are small with an average of herd size less than 8 cows per farmer. The farmers whose income was received as in-kind were found to be more likely to adopt innovative technology in the absence to the access of credits. In this context, the government should improve the farm income of farmers to encourage technologies adoption. This could be through improving farmers' creditworthiness and opening/facilitating the door to agricultural credit and inputs. Agricultural insurance also can act as a catalyst for enhanced productivity. The study showed the importance of the institutional variables on the decision to adopt IT. The participation of farmers in associations has a positive influence on the technology adoption. It helped introduce appropriate legislation benefiting livestock from national incentives and it provides an opportunity for the integration of smaller, poorer producers to improve their livelihoods. The association volunteers to be the guarantor for small flock owners who are in need for loans from the bank. However, the number of agricultural association in Tunisia is very low about 1267 for the Agricultural Development Groupings (GDA) and 177 for the Mutual Agricultural Services Company in 2012, the two major forms of agricultural organization in Tunisia. The government should relax the status of these organi- zations to have more flexibility and should give more advantages to farmers for becoming members of these organizations. The results showed also the important role of extension services on the adoption decision. In this direction, the Government should provide agricultural extension with sufficient financial and material resources, human resources and adequate training on modern technologies. In addition, strengthening the link between research activity and extension activity through a participatory approach where all stakeholders are included (researchers, extension agents, civil societies, public and private institutions, targeted farmers, etc.) is crucial to enhance the adoption of IT. Extension approaches' components include access to technical information, to market information, and to inputs (improved seeds, livestock management, or fertilizer). Actually, an appropriate extension approaches with most desirable impacts on technology adoption, agricultural productivity and households (including women and youth) livelihoods are urgently needed. Understanding which extension approaches has the greatest impacts will certainly improve the widespread of the innovation and, consequently the future of out-scaling. A comprehensive strategy should be developed on the mechanisms to implement an improved extension framework in a cost effective and gender sensitive approaches.

The source of technology knowledge variable SINF is statistically significant and positive at $1 \%$. This indicates the important role of accurate and sufficient information on the adoption of innovative technology (benefits, risks, Manuel of use, advantages, costs, etc.). In most cases, the innovative technology is introduced to farmers through a development project. To enhance the adoption of innovative technologies, the government should intensify training programs for farmers and for extension agents (by strengthening their competency aspects) in partnership with the development projects. Otherwise, the adoption of any technology remains dependent on its financial feasibility and its adaptation with the farmer's environment context.

This paper provides important information for government and policy makers to facilitate the introduction of innovative technologies to live- 
stock holders in arid area. However, the public institutions are not able to improve technologies adoption due to the lack of resources (financial, human) and the complexity of coordination between the main extension and development institutions (OEP, AVFA, and CRDA's). The recent involvement of the profession in the transfer of innovations is indeed an initiative which would pave the way for the liberalization of agricultural extension. In this sense, the Government is gradually considering withdrawing from this activity, giving way to the profession to ensure its support as it is the case in developed countries. (Khaldi et al., 2010). In this context, a frame agreement was signed on March 1, 2019 between the Ministry of Agriculture, Water Resources and Fisheries and the Tunisian Union of Agriculture and Fisheries (UTAP) for the establishment of a pilot public-private experiment in the field of agricultural extension in areas where there is a lack of public extension agents. This agreement aims to enhance the rate of farmer's supervision, to improve the quality of extension services and to strengthen the link between the profession, institution and research in order to ensure a better adoption of innovations.

In addition, the implication of private sector to technologies dissemination is highly recommended especially towards the small farmers. In this way, two projects "Hlibna" and "Evolution" were launched by milk plant "Delice-Danone" for small and medium-sized farmers. The "Hlibna" project has provided training sessions on the field and technical know-how to improve farming conditions, yield and income. This project has reached 1.500 farmers and this number will reach 5.000 by 2020 . The "Evolution" project currently affects 40 farms and aims to reach 150 by 2020 (ONAGRI, 2016). These farms have high breeding potential but they are underexploited.

Furthermore, a participatory approach at all levels, research and extension is strongly recommended. A better coordination between the different links in the livestock sector (farmers, industrials, wholesaler, retail, policy makers, consumers, etc.) is essential to ensure the best possible adoption of innovative technologies. In this sense, the open innovation strategy in- cluding all stakeholders during idea generation could be considered as a better way to decrease technology development costs and improve innovative technologies adoption (Seyfettinoğlu, 2016).

\section{Acknowledgements}

This work was done in the framework of the PARI-FARA project. This project brings together partners from Africa, India and Germany to contribute to sustainable agricultural growth and food and nutrition security in Africa and India as part of the Agricultural Innovation Centers initiative supported by the German government. The authors gratefully acknowledge the financial support provided by the PARI-FARA project.

\section{References}

Abunga Akudugu M., Guo E., Kwesi Dadzie S., 2012. Adoption of Modern Agricultural Production Technologies by Farm Households in Ghana: What Factors Influence their Decisions? Journal of Biology, Agriculture and Healthcare, 2(3).

Akroush S., Dhehibi B., Dessalegn B., Taysir O., Hadidi T., Abo-Roman M., 2017. Factors Affecting the Adoption of Water Harvesting Technologies: A Case Study of Jordanian Arid Area. Sustainable Agriculture Research, 6: 80-89, ISSN: 1927-050X. Aldrich J.H, Nelson D.F., 1984. Linear Probability, Logit and Probit Models. Londo: Sage Publications, 95 pages.

Amadou S., 2005. Farm-level adoption of soil and water conservation techniques in northern Burkina Faso, Agricultural Water Management, 71: 211224.

Aziza M., Raoudha K., Gley K., 2009. The adoption of technical and organizational innovations and their impact on the dairy sheep breeding in Tunisia. New Medit, 8(3): 36-40.

Bedhiaf S., Ben Salem H., Nefzaoui A., 2005. Small ruminant management in M\&M Project. Small Ruminant CD-ROM (ILRI-ICARDA-INAT-INRAT-USDA), http://64.95.130.4/.

Bedhiaf S., Daly H., Dhehibi B., Dhraief M.Z., Oueslati M., Gamoudi A., Rebhi B., Abbassi S., 2016. Innovation platform, farmers' organization and market to empower small farmers benefit from an autochthonous meat sheep value chain under low input production systems. FAO-CIHEAM, Options Méditerranéennes, 115: 327-332. 
Bedhiaf-Romdhani S., Djemali M., Zaklouta M., Iniguez L., 2008. Monitoring crossbreeding trends in native Tunisian sheep breeds. Small Ruminant Research, 74: 274-278.

Ben Salem H., Zaibet L., Ben-Hammouda M., 2006. Perspectives de l'adoption du semis direct en Tunisie. Une approche économique. In: Arrue Ugarte J.L., Cantero-Martínez C. (eds.), Troisièmes rencontres méditerranéennes du semis direct. Zaragoza: CIHEAM, 69-75 (Options Méditerranéennes: Série A. Séminaires Méditerranéens; n. 69).

Conley T.G., Udry C.R., 2010. Learning about a new technology: Pineapple in Ghana. American Economic Review, 100(1): 35-69.

Dhehibi B., Zucca C., Frija A., Kassam S.N., 2018. Biophysical and econometric analysis of adoption of soil and water conservation techniques in the semiarid region of Sidi Bouzid (Central Tunisia). New Medit, 2: 15-28.

Djemali M., Bedhiaf-Romdhani S., Iniguez L., Nouno M.I., 2009. Saving threatened native breeds by autonomous production, involvement of farmer's organization, research and policy makers: The case of the Sicilo-Sarde breed in Tunisia, North Africa. Livestock Science, 120: 213-217.

Elloumi M., Selmi S., Ben Salem H., Bedhiaf S., Hamadi H., El Faleh M., Chouki S., Atti N., Nefzaoui A., 2005. Adoption and impact studies in Tunisia. In: Shideed K.H., El-Mourid M. (eds), Adoption and impact assessment of improved technologies in crop and livestock production systems in the WANA region. Aleppo: ICARDA, 139-160.

Fernandez-Cornejo J., Mishra A., Nehring R., Hendricks C., Southern M., Gregory A., 2007. Off-farm income, technology adoption, and farm economic performance. Agricultural Economics Report, Washington, DC: USDA ERS. n. 36, 53 pages.

Fouzai A., Smaoui M., Frija A., Dhehibi B., 2018. Adoption of Conservation Agriculture Technologies by Smallholder Farmers in the semiarid region of Tunisia: Resource constraints and partial adoption. Journal of New Sciences, 6(1): 105-114.

Goodwin B., Mishra A., 2002. Farming Efficiency and the Determinants of Multiple Job Holding by Farm Operators. American Journal of Agricultural Economics, 86: 722-729.

Haddad N., El Mourid M., Nefzaoui A., 2007. Mashreq and Maghreb Project Achievements and Lessons Learnt. Aleppo: ICARDA, 90 pages.

INS, National Institute of Statistics, Statistical yearbook of Tunisia, 2016 (in Arabic).

Kariyasa K., Dewi Y.A., 2011. Analysis of Factors Affecting Adoption of Integrated Crop Management
Farmer Field School (Icm-Ffs) in Swampy Areas. International Journal of Food and Agricultural Economics, 1(2): 29-38.

Katungi E., Akankwasa K., 2010. Community-Based Organizations and Their Effect on the Adoption of Agricultural Technologies in Uganda: a Study of Banana (Musa spp.) Pest management technology. Acta Hortic., 879: 719-726, DOI: 10.17660.

Khaldi R., Dhraief M.Z., Albouchi L., 2010. Innovations institutionnelles face à la crise pour une meilleure adoption des innovations techniques des céréales irriguées en Tunisie. ISDA 2010, Juin 2010, Montpellier, France. Cirad-Inra-SupAgro, 13 pages.

Khalid M., Al-Badri B., Dhehibi B., 2017. Economic Analysis of the Factors Affecting the Adoption of Sub SurfaceIrrigation Technology in Iraq. International Journal of Science and Research (IJSR), 6: 1777-1783, ISSN (Online): 2319-7064.

Lavison R.K., 2013. Factors Influencing the Adoption of Organic Fertilizers in Vegetable Production in Accra, Msc Thesis, Accra, Ghana, 131 pages.

Loevinsohn M., Sumberg J., Diagne A., Whitfield S., 2012. Under what circumstances and conditions does adoption of technology result in increased agricultural productivity?, protocol. London: EPPI Centre, Social Science Research Unit, Institute of Education, University of London, 23 pages.

Mauceri M., Alwang J., Norton G., Barrera V., 2005. Adoption of Integrated Pest Management Technologies: A Case Study of Potato Farmers in Carchi, Ecuador; Selected Paper prepared for presentation at the American Agricultural Economics Association Annual Meeting, Providence, Rhode Island, July 24-27, 2005, 28 pages.

Mignouna D.B., Manyong V.M., Rusike J., Mutabazi K.D., Senkondo E.M., 2011. Determinants of Adopting Imazapyr-Resistant Maize Technology and its Impact on Household Income in Western Kenya. AgBioforum, 14: 158-163.

Mwangi M., Kariuki S., 2015. Factors Determining Adoption of New Agricultural Technology by Smallholder Farmers in Developing Countries. Journal of Economics and Sustainable Development, 6: 200-207.

Namara R.E., Weligamage P., Barker R., 2003. Prospects for adopting system of rice intensification in Sri Lanka: A socioeconomic assessment. Research Report 75. Colombo, Sri Lanka: International Water Management Institute, 46 pages.

Nefzaoui A., Ben Salem H., El Mourid M., 2011a. Innovations in small ruminants feeding systems in arid Mediterranean areas. In: Bouche R., Derkimba 
D., Casabianca F. (eds.), New trends for innovation in the Mediterranean animal production. EAP Publication, 12: 99-116. Wageningen: Wageningen Academic Publisher.

Nefzaoui A., Ketata H., El Mourid M., 2011b. Agricultural Technological and Institutional Innovations for Enhanced Adaptation to Environmental Change in North Africa. In: Young S.S., Silvern S.E. (eds.), International Perspectives on Global Environmental Change, Intech, ISBN : 978-953-307-815-1.

Nefzaoui A., Salman A., El Mourid M., 2008. Sheep husbandry and Reproduction Improvement in Low-Rainfall Areas of West Asia and North Africa. IDRC, Cairo, KARIANET/IDRC-ICARDA-IFAD booklet, 26 pages.

Ng'ombe J., Kalinda T., Tembo G., Kuntashula E., 2014). Econometric Analysis of the Factors that Affect Adoption of Conservation Farming Practices by Smallholder Farmers in Zambia. Journal of Sustainable Development, 7: 124-138, ISSN: 19139063.

ONAGRI (Observatoire National de l'agriculture Agricole), 2016. Annuaire statistique, 190 pages, http:/www.onagri.nat.tn/uploads/statistiques/annuaire\%20statistique2016.pdf.

Reardon T., Kostas S., Prabhu P., 2007. Rural Nonfarm Employment in Developing Countries in an era of Globalization. Agricultural Economics, 37: 173-183.

Rogers E.M., 1995. Diffusion of Innovations. New York: Simon \& Schuster.

Rogers E.M., 2003. Diffusion of Innovations. New York: Free Press, 551 pages.

Samiee A., Rezvanfar A., Faham E., 2009. Factors affecting adoption of integrated pest management by wheat growers in Varamin County, Iran. African Journal of Agricultural Research, 4: 491-497.

Seyfettinoğlu Ü.K., 2016. Analysis of relationships between firm performance and open innovation strategies and stages in the Turkish food and beverage industry. New Medit, 15(1): 42-52.

Silva K.N.N., Broekel T., 2016. Factors constraining Farmers' adoption of new Agricultural Technology Programme in Hambantota District. In: Sri Lanka: Perceptions of Agriculture Extension Officers, 13th International Conference on Business Management 2016, 378-398.

Simtowe F., Zeller M., 2008. The Impact of Access to Credit on the Adoption of hybrid maize in Malawi: An Empirical test of an Agricultural Household Model under credit market failure, 2007 Second International Conference, August 20-22, 2007, Accra, Ghana, 52076, African Association of Agricultural Economists (AAAE). 